\title{
Studi Kelayakan Perangkap CO2 Berdasarkan Analisa Fisik Sedimen (Studi Kasus : Formasi Kabuh, Cekungan Jawa Timur Utara)
}

\author{
I Putu Khrisna Wijaya1, Wien Lestari2, Nita Ariyanti3, Juan Pandu4, Firmansyah Saifuddin5, Widya Utama6, \\ Ayi Saeful Bahri7 \\ 1. Fakultas Teknik Sipil Dan Perencanaan, Jurusan Teknik Geofisika, Institut Teknologi Sepuluh November \\ *wienlestari02@gmail.com
}

\begin{abstract}
Abstrak
Peningkatan Pengembangan Produksi Minyak dan Gas di Jawa Timur menghasilkan $\mathrm{CO}_{2}$ lebih dari 2 juta ton/tahun. CCS (Carbon Capture and Storage) adalah upaya mitigasi mengurangi pemanasan global dengan menangkap dan menyimpan $\mathrm{CO}_{2}$ di dalam formasi batuan sedimen dengan porositas dan permeabilitas tinggi. Tujuan penelitian ini untuk mengevaluasi potensi penerapan CCS di cekungan Jawa Timur. Formasi Kabuh yang terletak di Zona Kendeng menjadi objek studi kelayakan sebagai perangkap $\mathrm{CO}_{2}$. Formasi $\mathrm{Kabuh}_{\text {berumur }}$ Pleistocene (N23) terdiri dari batu pasir dengan bahan non-vulkanik, mengandung kuarsa, crossbedding dengan konglomerat dan tuf, fosil vertebrata (N23) dan molusca. Sedimen ditandai dengan intensifikasi trough-jenis crossbedding, mengandung fragmen berukuran kerikil. Penelitian CCS ini menggunakan metode kuantitatif berupa analisa formasi meliputi ukuran butir, makroskopik and megaskopis petrologi, mineral dan analisa fosil, analisa struktur geologi serta menghitung kelurusan dan struktur yang dominan di daerah penelitian. Analisa Metoda Kuantitatif diharapkan menjadi penilaian Formasi Kabuh yang mungkin memenuhi persyaratan sebagai perangkap $\mathrm{CO}_{2}$

Kata kunci:CCS, Kabuh, Sedimen, Reservoir
\end{abstract}

\section{PENDAHULUAN}

\subsection{Latar Belakang}

Pada saat ini isu pemanasan global (global warming) akibat peningkatan jumlah karbondioksida $\left(\mathrm{CO}_{2}\right)$ menjadi isu yang sering dibahas oleh para akademisi dan professional serta pemerintah. Banyak industri terutama pada bidang minyak dan gas yang kurang memperhatikan dampak tentang emisi yang dihasilkan, sedangkan penurunan emisi karbon dapat dilakukan dengan cara yang ramah lingkungan. Indonesia berencana untuk mengurangi emisi $\mathrm{CO}_{2}$ sebesar $26 \%$ pada tahun 2020 , namun tantangannya adalah masih banyak produksi gas alam yang melepaskan $\mathrm{CO}_{2}$ ke atmosfer bumi sampai saat ini seingga hal ini dapat menghambat rencana tersebut. Masalah ini dapat ditanggulangi dengan menciptakan suatu system yang dapat menangkap dan menyimpan karbondioksida $\left(\mathrm{CO}_{2}\right)$ dimana $\mathrm{CO}_{2}$ yang dihasilkan selama proses produksi gas alam akan ditangkap dan disimpan di dalam tanah (subsurface).Teknologi tersebut dinamakan CCS (Carbon Capture and Storage). Salah satu formasi yang berpotensi sebagai tempat disimpannya $\mathrm{CO}_{2}$ adalah batupasir yang memiliki sifat berpori atau memiliki porositas baik. Batupasir Formasi Kabuh dipilih karena berpotensi untuk tempat disimpannya $\mathrm{CO}_{2}$ dalam system CCS (Carbon Capture and Storage).

\subsection{Rumusan dan Batasan Masalah}

Batupasir memiliki karakteristik yang berbeda di setiap tempat atau lingkungan pengendapannya. Penelitian ini adalah studi karakteristik meliputi karakteristik butiran dan mineral dari batupasir Formasi Kabuh Jawa Timur untuk CCS (Carbon Capture and Storage). Jawa Timur memiliki produksi gas yang cukup besar karena terdapat cekungan migas yang cukup besar yaitu NEJB (North East Java Basin) diantaranya lapangan Kangean di Madura, Bojonegoro, Tuban, West Madura Ofshore, dll sehingga pemanfaatan CCS (Carbon Capture and Storage) sangat perlu dan batupasir Formasi Kabuh ideal untuk menyimpan $\mathrm{CO}_{2}$.

\subsection{Maksud dan Tujuan}

Tujuan dari pemanfaatan Carbon Capture And Storage (CCS) adalah untuk :

1. Peningkatan Laju Produksi Migas (Enhanced Oil Recovery)

2. Pengurangan emisi $\mathrm{CO} 2$ yang semakin meningkat 
Sedangkan maksud dari penelitian ini adalah melakukan studi karakteristik batupasir pada Formasi Kabuh meliputi analisis fisik sedimennya untuk mengetahui kelayakan untuk menjadi reservoir CCS.

\section{TINJAUAN PUSTAKA}

\subsection{Formasi Kabuh Cekungan Jawa Timur Utara}

Menurut Van Bemmelen tahun 1949 tentang Fisiografis Pulau Jawa, daerah Jawa Timur memiliki beberapa zona diantaranya adalah Zona Rembang, Zona Kendeng, Gunung Api Kuarter, dan Zona Pengunungan Selatan bagian Timur. Formasi Kabuh termasuk kedalam Zona Kendeng.

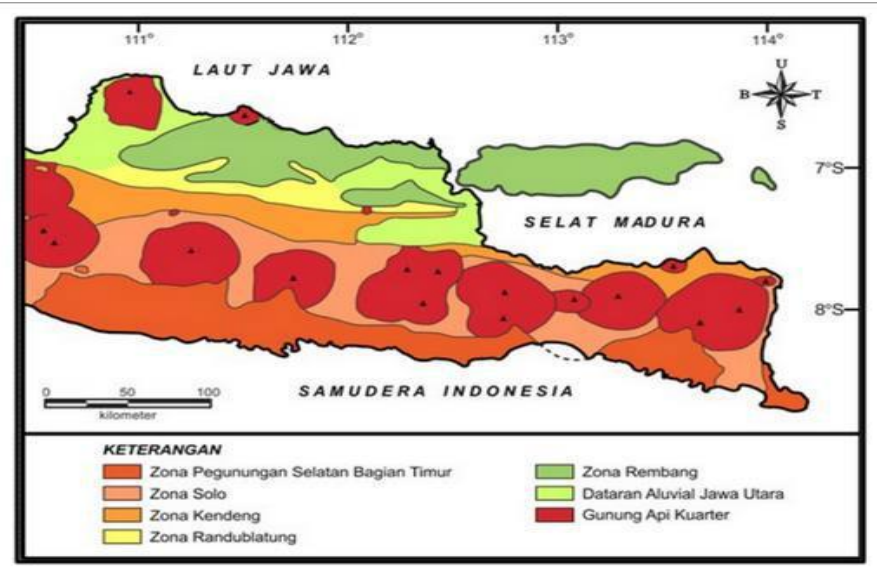

Gambar 2.1 Fisiografis Pulau Jawa Bagian Timur [1]

Menurut Harsono P. (1983) Stratigrafi daerah kendeng terbagi menjadi dua cekungan pengendapan, yaitu Cekungan Rembang (Rembang Bed) yang membentuk Pegunungan Kapur Utara, dan Cekungan Kendeng (Kendeng Bed) yang membentuk Pegunungan Kendeng. Formasi yang ada di Kendeng adalah (dari tua ke muda) adalah Formasi Kerek, Formasi Kalibeng, Formasi Pucangan, Formasi Kabuh, Formasi Notopuro, dan Formasi Undakan Bengawan Solo [2].

Formasi Kabuh terletak selaras di atas Formasi Pucangan. Formasi ini terdiri dari batupasir dengan material non vulkanik antara lain kuarsa, berstruktur silangsiur dengan sisipan konglomerat dan tuff, mengandung fosil Moluska air tawar dan fosil - fosil vertebrata berumur Plistosen Tengah, merupakan endapan sungai teranyam yang dicirikan oleh intensifnya struktur silangsiur tipe palung, banyak mengandung fragmen berukuran kerikil. Di bagian bawah yang berbatasan dengan Formasi Pucangan dijumpai grenzbank. Menurut Van Bemmelen (1972) di bagian barat Zona Kendeng (daerah Sangiran), formasi ini diawali lapisan konglomerat gampingan dengan fragmen andesit, batugamping konkresi, batugamping Globigerina, kuarsa, augit, hornblende, feldspar dan fosil Globigerina. Kemudian dilanjutkan dengan pembentukan batupasir tuffaan berstruktur silangsiur dan berlapis mengandung fragmen berukuran kecil yang berwarna putih sampai cokelat kekuningan [3]

Distibusi Formasi Kabuh pada daerah Jawa Timur banyak terdapat pada Kabupaten Jombang khususnya pada desa Kabuh, desa Kemlangi, dan desa Sumberingin. Pada ketiga daerah ini pemetaan geologi dilakukan dan pengambilan sampel dilakukan pada daerah ini pula.

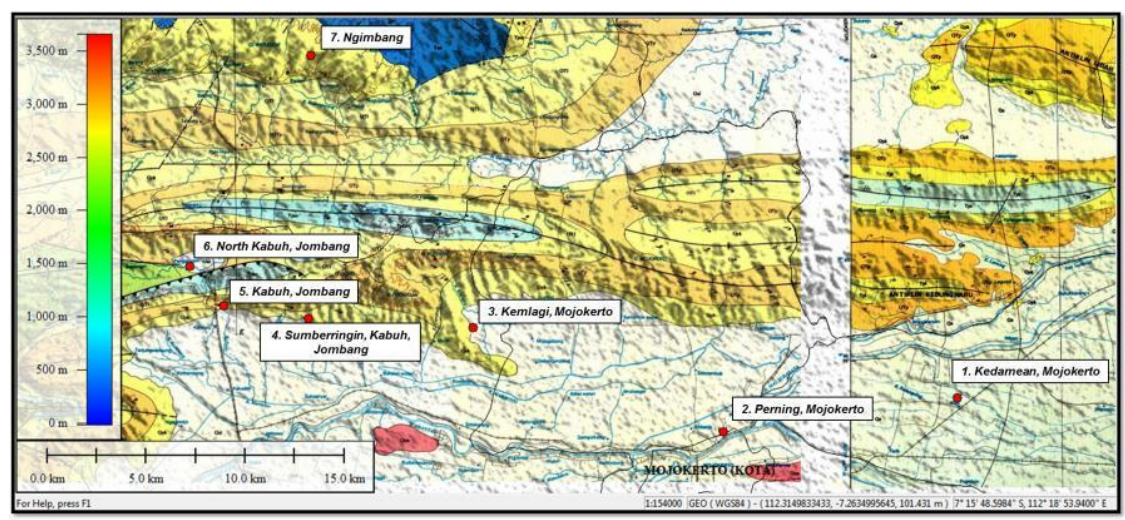

Gambar 2.2. Distribusi Pengendapan Formasi Kabuh Pada Kabupaten Jombang [4]

\subsection{Pemanfaatan Carbon Capture And Storage (CCS)}

Carbon Capture and Storage (CCS) adalah salah satu aplikasi untuk injeksi $\mathrm{CO} 2$ ke dalam reservoir dengan melalui sumur injeksi dengan fungsi meningkatkan laju produksi (EOR) atau untuk pengurangan emisi $\mathrm{CO}_{2} \mathrm{karena} \mathrm{CO} 2$ akan diikat dan diubah ke dalam bentuk yang cair dan selanjutnya dapat dimanfaatkan [5]. CCS memiliki kekurangan dalam perkembangannya, yaitu untuk melakukan metode ini cukup mengeluarkan banyak biaya. 
Mekanisme pemanfaatan CCS ini terdiri dari 3 tahapan, yaitu :

1. Penangkapan $\mathrm{CO}_{2}$ dari sesuatu penghasil $\mathrm{CO}_{2}$ misalnya dari pembangkit listrik

2. Pemindahan $\mathrm{CO}_{2}$ menjadi bentuk cair sehingga mudah untuk di transport. $\mathrm{CO}_{2}$ ini dikompresi menjadi cair agar mudah diangkut ketempat penyimpanan.

3. Penyimpanan $\mathrm{CO}_{2}$ dan tempat paling efektif untuk menyimpan emisi ini adalah pada reservoir yang sudah tua.

4. Pemantauan (monitoring)

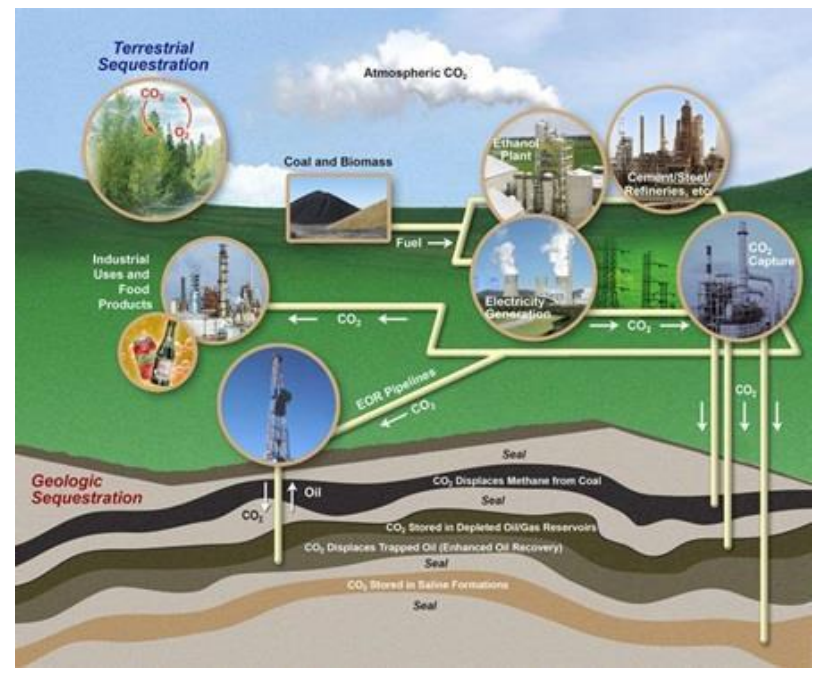

Gambar 2.3. Mekanisme Carbon Capture and Storage (CCS) (Yordan, 2015)

\section{METODE PENELITIAN}

\subsection{Pemetaan Geologi}

Pemetaan geologi yang dilaksanakan berpusat pada Desa Kabuh Jombang Jawa Timur, dilakukan secara bertahap, terdiri dari 2 tahap pemetaan geologi dimana fungsinya adalah :

1. Pemetaan geologi pertama dilakukan untuk reconnaissance yaitu pemetaan pendahuluan pada desa tertuju dimana endapan sedimen Formasi Kabuh banyak tersingkap sehingga memudahkan dalam proses pengambilan sampel batuan. Pengukuran struktur geologi juga dilakukan pada pemetaan geologi yang pertama.

2. Pemetaan geologi kedua dilakukan untuk integrasi Formasi batuannya, dimana peneliti mencari batas wilayah dimana Formasi Kabuh sudah tidak ditemukan endapannya lagi.

Setelah pemetaan geologi dilakukan dan peneliti memperoleh sampel batuan selanjutnya adalah analisis sampel batuan tersebut, sehingga dari hasil yang didapatkan melalui analisis laboratorium, tujuan penelitian untuk mengetahui karakteristik Formasi Kabuh didapatkan. Analisis ini sedang berlangsung hingga saat ini. Analisis sampel batuan membutuhkan proses yang cukup lama, adapun prosesnya adalah sebagai berikut :

a. Pengumpulan sampel batuan

b. Pembuatan preparat (preparasi batuan) dimana preparat adalah bentuk sayatan tipis batuan yang didapat dari sampel batuan dibuat dalam bentuk yang lebih kecil dan tipis untuk dapat dilihat pada mikroskop batuan. Sayatan tipis batuan digunakan untuk melihat mineral apa saja yang terkandung di dalam batuan tersebut. Sedangkan untuk analisis paleontologi batuan sedimen tersebut dipecahkan dan diayak sehingga butiran cangkang fosil vertebrata dapat terlihat dan kemudian dapat dilihat menggunakan mikroskop batuan dan memastikan jenis fosil tersebut.

\subsection{Metode Pengambilan Conto Batuan (Sample)}

Sampel batuan adalah bagian dari batuan yang dapat diambil untuk dianalisis karakteristiknya sehingga dapat dipelajari dan dianalisis lebih lanjut. Metode untuk pengambilan sampel disebut Metode Sampling. Kerdi Simbolon, 2010 membagi metode Sampling menjadi beberapa kelompok, diantaranya adalah

\section{Grab Sampling}

Secara umum, metode grab sampling ini merupakan teknik sampling dengan cara mengambil bagian (fragmen) yang berukuran besar dari suatu material (baik di alam maupun dari suatu tumpukan) yang mengandung mineralisasi secara acak (tanpa seleksi yang khusus). Tingkat ketelitian sampling pada metode ini relatif mempunyai bias yang cukup besar.

\section{Bulk Sampling}

Bulk sampling merupakan metode sampling dengan cara mengambil material dalam jumlah (volume) yang besar, dan umum dilakukan pada semua fase kegiatan (eksplorasi sampai dengan pengolahan). Pada fase sebelum operasi penambangan, bulk sampling ini dilakukan untuk mengetahui kadar pada suatu blok atau bidang kerja. Metode bulk sampling ini juga umum dilakukan untuk uji metalurgi dengan tujuan mengetahui recovery (perolehan) suatu proses 
pengolahan. Sedangkan pada kegiatan eksplorasi, salah satu penerapan metode bulk sampling ini adalah dalam pengambilan contoh dengan sumur uji

\section{Chip Sampling}

Chip sampling (conto tatahan) adalah salah satu metode sampling dengan cara mengumpulkan pecahan batuan (rock chip) yang dipecahkan melalui suatu jalur (dengan lebar $15 \mathrm{~cm}$ ) yang memotong zona mineralisasi dengan menggunakan palu atau pahat. Jalur sampling tersebut biasanya bidang horizontal dan pecahan-pecahan batuan tersebut dikumpulkan dalam suatu kantong conto. Kadang-kadang pengambilan ukuran conto yang seragam (baik ukuran butir, jumlah, maupun interval) cukup sulit, terutama pada urat-urat yang keras dan brittle (seperti urat kuarsa), sehingga dapat menimbulkan kesalahan seperti oversampling (salting) jika ukuran fragmen dengan kadar tinggi relatif lebih banyak daripada fragmen yang low grade.

\section{Channel Sampling}

Channel sampling adalah suatu metode (cara) pengambilan conto dengan membuat alur (channel) sepanjang permukaan yang memperlihatkan jejak bijih (mineralisasi). Alur tersebut dibuat secara teratur dan seragam (lebar 3-10 cm, kedalaman 3-5 cm) secara horizontal, vertikal, atau tegak lurus kemiringan lapisan.

Dan yang akan dilakukan untuk metode sampling pada batupasir Formasi Kabuh adalah metode grab sampling karena sampel batuan yang didapat berasal dari proses pemetaan langsung ke lapangan sehingga sampel batuan yang diambil acak dan tidak berdasar urutan yang pas karena tidak diperoleh melalui pemboran. Setelah beberapa batupasir didapat dari berbagai tempat di wilayah Kabuh, batupasir tersebut akan dibawa ke laboratorium dan dianalisis (Hand Spacement). Pemetaan geologi juga didapat data strike dan dip dari batupasir Formasi Kabuh [6]

\subsection{Dispersed Organic Matter (DOM)}

Dispersed Organic Matter (DOM) adalah salah satu analisis petrografis organic untuk mengetahui besar vitrinit reflektan atau kematangan termal (thermal maturation). Analisis DOM juga memperlihatkan kenampakan fosil, pecahan fosil dari suatu batuan. Beberapa vitrinit reflektan tersebut dapat memperlihatkan ciri khas lingkungan pengendapan dari suatu batuan. Pada akhirnya analisis DOM ini dapat digunakan untuk menganalisis seberapa matang dari material organic yang terkandung pada suatu batuan tertentu.

\section{HASIL DAN PEMBAHASAN}

Hasil pengamatan pada STA 4, 4A dan 11 meliputi analisis megaskopis yaitu dari hasil pengamatan geologi lapangan selanjutnya mengambil sampel batuan dan kemudian dianalisis Dispersed Organic Matter pada laboratorium. Semua batuan yang ditemukan pada daerah penelitian adalah batupasir dengan pecahan cangkang moluska dan fragmen konglomeratan. Tuff hanya dijumpai pada sebagian kecil wilayah saja. Hasil pengamatan menunjukkan lingkungan pengendapan dari Formasi Kabuh yaitu Neritik-Neritik Tengah dan umur pengendapannya adalah Plistosen (N23). Hasil pengamatan pada STA 4 adalah batupasir tersebut mengandung oksida besi, pirit, liptinit, gaukonit dan mengandung pecahan cangkang vertebrata.

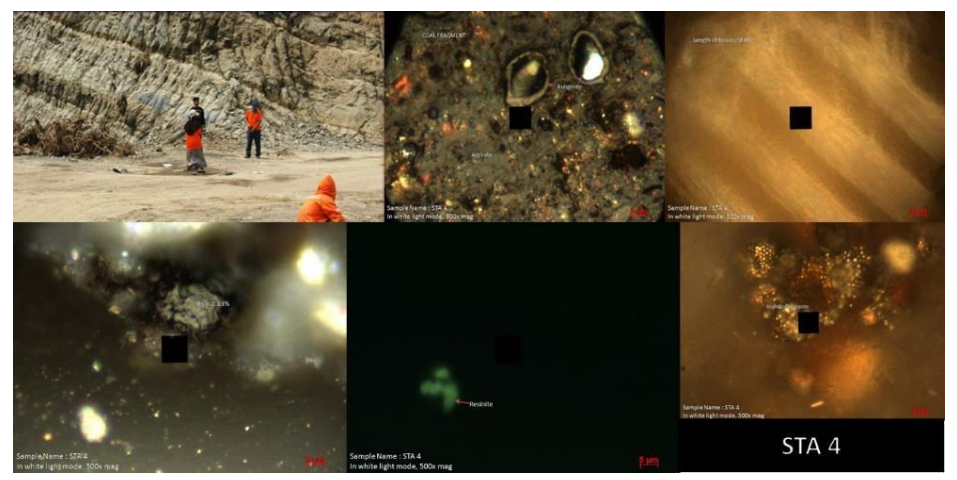

Gambar 4.1. Hasil Pengamatan Outcrop dan Dispersed Organic Matter STA 4 (Desa Kabuh)

Sedangkan pada STA 4A yang terletak tidak jauh dari pengamatan pada STA 4 maka hasil analisis laboratoriumnya tidak jauh berbeda hanya beberapa unsur-unsurnya mulai jarang terlihat seperti glaukonit, pirit, dan oksida besi.Pada STA 11 cangkang semakin jarang terlihat dan unsur-unsur lain ada yang hilang.

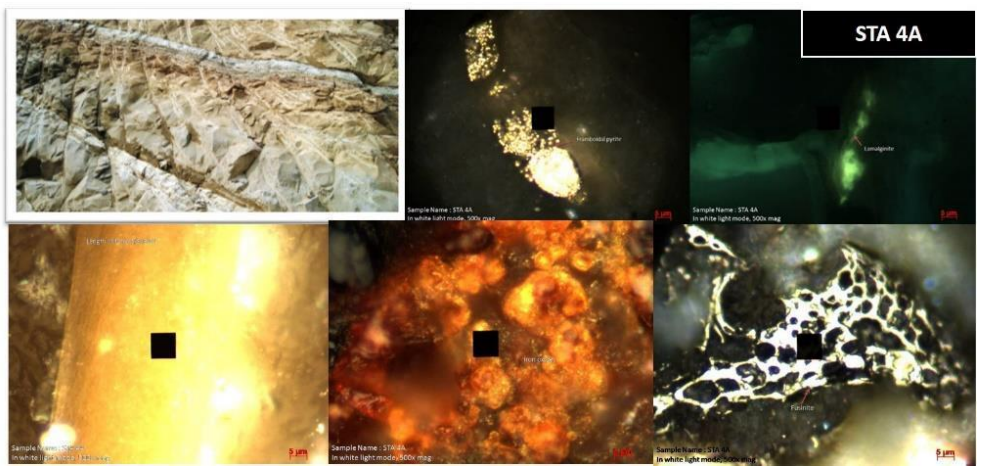


Tiga sampel singkapan adalah sampel batuan klastik sedimen baik dianalisis untuk reflektansi (Maturity / rank) dan konten maseral. Secara mikroskopis, sampel secara keseluruhan terdiri dari bahan organik dan materil anorganik. Semua sampel didominasi oleh vitrinit maseral. Liptinite maseral yang paling banyak adalah Resinite yang ditemukan dalam sampel STA 4 dan STA 11. Lamalginite maseral ditemukan dalam sampel STA 4A. Lamalginite ditandai dengan bentuk lamelae atau tali tipis, menunjukkan intensitas fluoresensi sedang kuning ke oranye. Kehadiran lamalginite (alginite) mungkin menunjukkan area lingkungan pengendapan yang ditutupi oleh kelimpahan air dan dalam waktu yang relatif lama, seperti endapan danau atau laut dangkal. Hal ini juga didukung oleh kehadiran pirit framboidal berlimpah inthose sampel. Inertinit juga hadir dengan sifat minor . Foraminifera / Shell tidak ditemukan secara signifikan di semua sampel. Maksimum vitrinit nilai reflektansi yang berkisar dari 0,23\% menjadi 0,36\%, menunjukkan sumber yang belum matang (immature). Sampel dengan VRmax $<0,5 \%$ mengindikasikan batuan induk yang belum matang. Semua sampel memiliki Standard relatif tinggi nilai-nilai deviasi lebih tinggi yang 0,05 sebagai akibat dari variasi besar dalam nilai-nilai vitrinit reflektansi, mungkin disebabkan oleh kondisi yang tidak stabil selama pengendapan mereka batuan sedimen yang kaya organik. Total jumlah oksida besi hanya $<1 \%$. Ini mungkin menunjukkan tidak signifikan suatu pelapukan di daerah tersebut

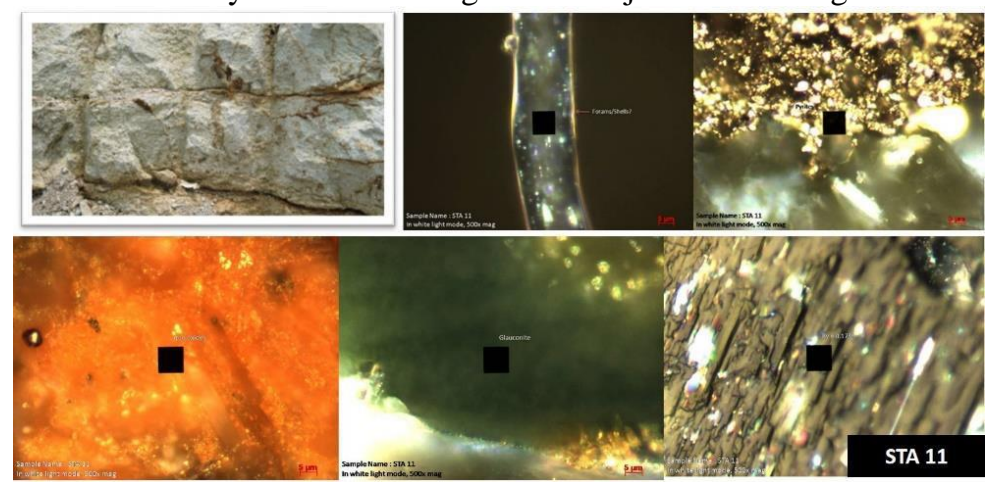

Gambar 4.2. Hasil Pengamatan Outcrop dan Dispersed Organic Matter STA 11 Daerah Kemlangi

\section{KESIMPULAN}

Formasi Kabuh adalah Formasi dengan anggota satuan litologi batupasir dengan butiran kasar sampai halus, konglomeratan, tuff di sedikit tempat dijumpa, berumur Plistosen (N23) dengan lingkungan pengendapan laut dangkal. Formasi Kabuh dapat dimanfaatkan sebagai reservoir penyimpanan CO2 pada aplikasi CCS di Jawa Timur tetapi harus ada studi lanjut tentang porositas pada Formasi Kabuh. Manfaat CCS untuk EOR tidak dapat diaplikasikan karena umur reservoir ini yang masih relative muda dan mengandung material organic yang belum matang sehingga masih belum dapat di produksi kandungan minyak dan gasnya.

\section{DAFTAR PUSTAKA}

[1] V. Bemmelen, Fisiografi Pulau Jawa. Jakarta, 1949.

[2] H. P, Geologi Cekungan Jawa Timur Utara. Jakarta: Jakarta, 1983.

[3] V. Bemmelen, Geologi Zona Kendeng. Jakarta, 1972.

[4] S. Hadi, Distribusi Formasi Kabuh Pada Kabupaten Jombang. Jakarta, 1998.

[5] ESDM, Penggunaan Carbon Captured and Storage. Jakarta.

[6] K. Simbolon, Mekanisme Sampling Batuan. Bandung, 2010. 